\title{
Application of Lean Six Sigma Approach to Reduce Worker Fatigue in Racking Areas Using DMAIC, VSM, FMEA and ProModel Simulation Methods in Sub Logistic Companies: A Case Study of Indonesia
}

\author{
Jakfat Haekal \\ Faculty of Engineering \\ Industrial Engineering Department \\ Universitas Mercu Buana \\ Indonesia
}

\begin{abstract}
A logistics company is a company engaged in providing services for receiving, storing, and shipping goods belonging to the leading company; these goods can be in the form of benthic materials, semi-finished materials, or finished materials. In day-today company activities, the company is obliged to provide a safe work environment from the dangers and risks of potential harm that employees may experience while working within the company premises. Based on this, this study aims to reduce the work risks in the shelf area. Therefore, the approach in this study uses the integer DMAIC method (Define, Measure, Analyze, Improve, Control), VSM (Value Stream Mapping), and FMEA (Failure Mode Effect Analyze), and simulations using ProModel software. The DMAIC, VSM, and FMEA methods succeeded in determining the factors causing the damage to work facilities, namely human factors, equipment factors, environmental factors, and system factors in the company. ProModel simulation can show the difference in processing time before repairs and after repairs are made.
\end{abstract}

Keywords: DMAIC, VSM, FMEA, ProModel, Simulation.

\section{INTRODUCTION}

The coronavirus pandemic (Covid-19), which has not subsided, creates uncertainty in the Indonesian economy. The government also corrected economic growth prediction from 2.3 percent to minus 0.4 percent to 1 percent by 2020 . The economic contraction was reflected in sluggish business activities. However, several business sectors are growing, such as the e-commerce business, the food, beverage sales business, and shipping and couriers. On May 5, 2020, the Central Statistics Agency (BPS) released Indonesia's economic growth (Gross Domestic Product) for the first quarter of 2020 of 2.97\% (yon-y), compared to the fourth quarter of 2019, a decline of $2.41 \%$. Based on BPS data, Supply Chain Indonesia (SCI) recorded a growth in the logistics sector (transportation and warehousing business fields) in the first quarter of 2020 of $1.27 \%$ (yon-y). At present, working during a pandemic is risky, especially for groups of people who are susceptible to contracting the virus and workers in occupations who must continue to operate but do not implement a work from home system and apply health protocols in the work environment. What can be done is to identify whether the regulations that have been implemented in the workplace are by government guidelines and urge workers who have symptoms of being infected with COVID-19 not to come to work, arrange for the isolation of anyone who has symptoms of COVID-19 at work. While awaiting transfer to an appropriate health facility, routinely disinfect the workplace and provide health surveillance to persons in close contact with the infected worker [1-3]. Work safety requirements as stipulated in Law No.1 of 1970 concerning occupational safety and health article 3 paragraph 1 part a: "Preventing and reducing accidents," section h: "Preventing and controlling occupational diseases, both physical and psychological, poisoning, infection, and transmission," each company is obliged to provide personal protective equipment facilities and measures to prevent and reduce occupational risks. A work accident (accident) is an unwanted incident or event that harms humans, damages property, or damages the process [4-5]. Work accident is a risk that will occur if you do a job without paying attention to work safety aspects. Risk management can be carried out to reduce it, namely a structured and systematic process of identifying, measuring, mapping, developing alternative risk management, and monitoring and controlling risk management [6-7-8]. Work areas with a high work risk within the scope of warehousing include loading and unloading goods, placing goods on racks, picking up goods on racks, using lifting tools, and the arrival departure of transport cars. 
In warehousing, the area with a high level of mobility is the rack area, where the movement of goods in and out of all occurs in the rack area and the use of lifting tools (MHE / Manual Handling Equipment). Work risks that can occur in the shelf area include MHE hitting the shelf protectors (barrier and bullnose), pallets used in a damaged condition, asymmetrical product arrangement, untidy plastic wrapping. Cracked barriers and bullnose can be scratched or even dented, requiring repair to keep them functioning correctly. Repair or replacement of damaged barriers and bullnose, of course, requires many costs and includes company expenses that can be prevented or reduced. To reduce damage to company facilities, it can be covered with an initial assessment of each area's work risks, then repairing it with the appropriate method. The following is data on damage to company facilities in the shelf area at the research location during July 2019 - July 2020.

Table 1 Facility Repair costs for the period July 2019 - July 2020

\begin{tabular}{|l|c|c|c|c|}
\hline \multicolumn{1}{|c|}{ Description } & Total & $\begin{array}{c}\text { Number Of } \\
\text { Damaged }\end{array}$ & Repair Price & $\begin{array}{c}\text { Total Repair } \\
\text { Cost }\end{array}$ \\
\hline Barrier & 315 & 58 & IDR 300,000 & IDR $17,400,000$ \\
\hline Bullnose & 3000 & 738 & IDR 65,000 & IDR $47,970,000$ \\
\hline Beam & 3333 & 8 & IDR 235,000 & IDR $1,880,000$ \\
\hline Upright & 30000 & 3 & IDR $3,000,000$ & IDR $9,000,000$ \\
\hline \multicolumn{4}{|r}{} \\
\end{tabular}

Table 2 Damage to facilities for the period July 2019 - July 2020

\begin{tabular}{|c|c|c|c|c|c|}
\hline Description & Scratched & Dent & Severe & Broken Bolt & Total \\
\hline Barrier & 35 & 17 & 0 & 6 & 58 \\
\hline Bullnose & 517 & 132 & 78 & 11 & 739 \\
\hline Beam & 0 & 5 & 0 & 3 & 8 \\
\hline Upright & 0 & 3 & 0 & 0 & 3 \\
\hline
\end{tabular}

In the table above the number of damaged units in units, the most damaged facilities are 783 units, namely bullnose, which is the protector of each shelf's leg. The number of damaged is 58 units for barriers, namely side shelf protective fences, office building protectors, and pedestrian protection. Damage to the beam (shelves) and upright (rack poles) also occurred as many as 8 and 3 units; in OHSAS 18001: 2007, the hierarchy of hazard and risk control is the elimination, substitution, technical control, administrative control, and use of personal protective equipment. To determine the appropriate hierarchy of control, it is necessary to identify existing problems; DMAIC is a problem-solving procedure widely used in quality improvement and process improvement problems [9-10-11]. In addition to using the DMAIC method, another method used is the FMEA (Failure Mode Effect Analysis) method. FMEA is a method of evaluating the possibility of a system, design, process, or service failure to make handling steps [12-13-14-15]. During the research period, to help see the overall development and see if obstacles require a longer time for the repair process. In this case, the researcher uses VSM (Value Stream Mapping). Value Stream Mapping is a visual method for mapping and information from each workstation. This VSM can be used as a starting point for companies to identify waste and identify its causes. Using value stream mapping means starting with the big picture to solve problems in single processes and make overall improvements and not just on specific processes. VSM is depicted with symbols representing the activity. There are two activities: value-added and non-value added [16-17]. A control chart or control chart is also used in this research. A control chart is a technique known as a graphic method used to evaluate whether a process is under statistical quality control or not to solve problems and produce improvements.

After making repairs using the DMAIC, VSM, FMEA, and control chart methods. Furthermore, the latest process simulation is carried out. Simulation is a technique to imitate the operations or processes that occur in a system with computer devices' help and is based on certain assumptions so that the system can be studied scientifically [18-19]. According to Kholil,et al., the objectives of the simulation are:

a. Determine the characteristics (average, minimum value, maximum value, variance, etc.) of variables based on different input conditions, parameter values, and model configurations so that the system's analysis can be carried out and its behavior is known. 
b. Compare the characteristics (average, minimum value, maximum value, variance, etc.) of variables based on different input conditions, parameter values, and model configurations. Each scenario's performance can be seen, and choose the alternative that has the best performance [20].

In the simulation, computers are used to study the system numerically, where data is collected to perform statistical estimates to obtain the system's original characteristics. Simulation is the right tool to use, especially if you have to do experiments to find the best comments from system components. Simulation implementation needs to be done because the system's direct test will take a significant amount of time and cost. The simulation approach begins with the construction of an actual system model [21]. Models are valuable tools for analyzing and designing systems. As an efficient communication tool, the model can show how an operation works and stimulate thinking about improving or improving it [22-23-24]. The model is designed to represent the objective reality; even though the model itself is not a reality of the natural world, it only pays attention to factors that are considered essential and ignores factors that are considered unimportant in the analysis carried out. The model must show how the various components in the system interact with each other to describe the system's behavior. After the model is made, the model is transformed into a computer program so that it is possible to simulate it [25]. The system is defined as collecting one or more interacting objects [3-5-9]. Objects are physical entities with specific characteristics or attributes.

\section{LITERATURE SURVEY}

\subsection{Risk Management}

Risk management is an approach that has a structure or methodology for managing uncertainty associated with threats. According to [22-23-24], risk management is an effort to identify, analyze and control risk in every company activity to obtain higher effectiveness and efficiency.

\subsection{Lean Manufacturing}

According to add Gasperz [17], lean is a continuous effort to eliminate waste, increase product added value, and provide customers value. Therefore, lean can be defined as a systematic and systematic approach to identify and eliminate waste or nonvalue added activities through continuous improvement radically by flowing products and information using internal and external customer and attraction systems to pursue excellence and excellence.

According to Gasperz [17], there are five basic principles of lean, namely:

a. Identify the value of products (goods and / services) based on the customer perspective, where customers want superior quality products at competitive prices with timely service.

b. Identify the process mapping on the value stream for each product.

c. Eliminate unnecessary waste from all activity along the value stream.

d. Organize so that materials, information, and products flow smoothly and efficiently throughout the value stream using a pull system.

e. Seek continuously for various techniques and tools of improvement to achieve excellence and continuous improvement.

\subsection{Six Sigma}

Six Sigma is a quality improvement tool based on the use of data and statistics. The term "sigma" is the Greek letter $\sigma$ used for the quantity of Standard Deviation or standard deviation in statistics.

Six Sigma's basic principle is product improvement by making improvements to the process so that the process produces the perfect product. In addition, six Sigma is oriented towards long-term performance through quality improvement to reduce errors, with zero failure targets (zero defects) on process capabilities equal to or more than six Sigma in standard deviation measures.

Six Sigma is a technique or method of controlling and improving quality dramatically that has been implemented by the Motorola company from 1987. This method was first developed by William B. Smith, Jr. Dan Mikel J. Harry of Motorola in 1981, when Bob Galvin was CEO of Motorola.

According to Heizer and Render, translated by Hirson Kurnia, Ratna Saraswati, David Wijaya (2015), the meaning of six Sigma is a program to save time, improve quality, and lower costs.

According to Gasperz [17], six Sigma is a vision of improving quality towards 3.4 failure of the unity of millions of opportunities for each transaction (goods/services) and is activity towards perfection.

\subsection{ProModel}

ProModel is a windows-based simulation software that is used to simulate and analyze a system. ProModel provides the right combination of usage, flexibility, and modeling a simple system to make it look more realistic. Things that need to be considered 
in modeling an entire system, namely how the system operates, material flow, operating logic, work resources, and work trajectories. In the ProModel, during the simulation, animation of ongoing activities can be observed, and the results will be displayed in tables and graphs that make it easier for analysis.

\section{RESEARCH METHODOLOGY}

The research method is the procedure for how research is carried out [20]. Another definition of the research method is the researchers' Method in collecting research data, such as interviews, observations, tests, and documentation [21]. Meanwhile, according to [23], the research method is a way to regain solutions to all problems.

\subsection{Types of Research}

The type of research used in this research is descriptive and Simulation with the following meanings:

a. Descriptive

According to Evans and Lindsay [13] the descriptive method examines the status of a group of humans, an object, a set of conditions, a system of thought, or a class of events in the present. This descriptive research aims to make descriptions, descriptions, or paintings systematically, factually, and accurately regarding the facts, characteristics, and relationships between the investigated phenomena.

In this research, the descriptive method is used to solve problems in the present and actual. With this method, data compilation, analysis, and interpretation of the meaning of the data collected or the variables studied will be carried out. This method has the characteristics of focusing on solving problems in the present and the actual, the data collected is first arranged, explained then analyzed.

b. Simulation

Simulation is a replication or visualization of a system's behavior, for example, an educational plan, which runs at a particular time. So it can be said that the Simulation is a model that contains a set of variables showing the main features of an actual living system. Therefore, simulation allows decisions that determine how the main characteristics can be modified naturally [13].

The results of this study were simulated using ProModel software to see changes in the process after improvements. This also makes it easier to see other possible constraints and facilitates management to improve the entire work system.

\subsection{Types of Data and Information}

The types of data used in this study are primary data and secondary data with the following details:

\section{Primary Data}

According to Kholil et al [20] primary data is data obtained or collected directly in the field by the person conducting the research or those concerned who need it. The primary data used in this study are:

These primary data include:

- Interview result.

- Results of field observations.

- Occupational accident data

- Damage data in the shelf area

\section{Secondary Data}

Secondary data is data obtained or collected by people researching existing sources [20]. Secondary data in this study, namely:

a. General company information

b. Data storage rack area layout

c. Method of work when operating a forklift

d. Company working hours data

e. Hourly operator productivity target data

f. Research supporting data (literature, books, journals, etc.)

\subsection{Data Collection Methods}

This study uses two data collection methods, namely:

a. In-depth interview method

In-depth interviews are the process of obtaining information for research purposes using face-to-face questions and answers between the interviewer and the respondent or the person being interviewed, with or without using interview guidelines where the interviewer and informants are involved in a relatively long social life [19]. 
Interviews were conducted with employees who worked in one of the logistic companies as operators who were in charge of operating various types of forklifts; interviews were also conducted with operational supervisors who regulated the process of receiving and sending goods.

\section{b. Observation method}

Observation is the activity of observing a job or an environment to get information directly. This observation is carried out to assess the operator's work behavior, the suitability of the behavior with the procedures applied, the work environment, the equipment used, and the suitability of the process with work procedures.

\subsection{Data Processing and Analysis Methods}

This study aims to analyze work risks and productivity in the shelf area. The results of this study are recommendations for companies to improve the safety of the work area. The data processing stages were carried out using the DMAIC method. The data analysis stage refers to the work risk measurement table and the hazard management hierarchy pyramid.

The data processing stages consist of 4 stages, namely:

1. Value Stream Mapping (VSM) is made by explaining the activities carried out in the rack area; the data required are time data, distance data, target data for the movement of goods, etc.

2. Identification of potential failures using the FMEA method

3. Determine control boundaries using a control chart

4. Creating a pro model simulation with the work process that has been improved

\section{RESULT AND DISCUSSION}

\subsection{Research Results}

This section discusses data collection and processing results using the DMAIC method, namely the define, measure, analyze, improve and control stages. As a result, it can be seen that employee productivity exceeds the targets that have been achieved. Furthermore, the improvements simulated with the pro model simulation show that changing the MHE path to one directly affects employee productivity to decrease but still reaches the predetermined target.

\subsubsection{Results of Operator Training Assessment}

Improvements that have been made include proper and correct forklift use training and training on occupational health and safety standards. In addition, assessment is carried out to assess the ability of operators before training and after training. The following is a table of the results of the operator training assessment.

Table 3 Assessment Results of Operator Training

\begin{tabular}{|c|l|c|c|}
\hline No & \multicolumn{1}{|c|}{ Name } & Pre test Score & Post Test Score \\
\hline 1 & Sawita & 75 & 85 \\
\hline 2 & Prawendi & 70 & 85 \\
\hline 3 & Setyo Wahyudi & 75 & 90 \\
\hline 4 & Purwanto & 75 & 95 \\
\hline 5 & Silo Nugroho & 75 & 90 \\
\hline 6 & Usup Supriadi & 70 & 90 \\
\hline 7 & Faizal & 65 & 85 \\
\hline 8 & Kelik & 70 & 100 \\
\hline 9 & Dodi Jaya & 55 & 85 \\
\hline 10 & Budi Sanjaya & 60 & 80 \\
\hline 11 & Rohili & 70 & 90 \\
\hline 12 & Ibnu Mussayyad & 70 & 90 \\
\hline 13 & Dede Yusuf & 70 & 85 \\
\hline 14 & Dwi Jaya & 80 & 100 \\
\hline 15 & Fahmi Noviar & 85 & 100 \\
\hline 16 & Hoerudin & 85 & 100 \\
\hline 17 & Rahmat Abi & 85 & 100 \\
\hline 18 & Ainun & 75 & 100 \\
\hline
\end{tabular}


International Journal of Engineering Research and Advanced Technology, Vol. 7, No. 6, June -2021

\begin{tabular}{|c|l|c|c|}
\hline No & \multicolumn{1}{|c|}{ Name } & Pre test Score & Post Test Score \\
\hline 19 & Ade Pradita & 70 & 100 \\
\hline 20 & Ahmid & 85 & 95 \\
\hline
\end{tabular}

The table above describes the results of the pre-test assessment, with a minimum score of 70 . There are three employees with low scores, namely Faizal with a score of 65, Dodi Jaya with a score of 55, and Budi Sanjaya with a score of 60. Post-test assessments have higher results, and all employees get the value is more than the minimum value. Several employees get 100, including Kelik, Dwi, Fahmi Noviar, Khoerudin, Rahmat Abi, Ainun, and Ade Pradita.

\subsubsection{Results of RPN Assessment using the FMEA Method}

After the improvements have been made, the risk assessment is again carried out using the FMEA method by assessing the severity, incidence rate, and detection rate. The RPN calculation after the repair has decreased, as shown in the table below.

Table 4 Results of RPN Assessment using the FMEA

\begin{tabular}{|c|c|c|c|c|c|c|c|c|c|c|c|c|c|}
\hline $\begin{array}{l}\mathrm{N} \\
\mathrm{O}\end{array}$ & Job desk & $\begin{array}{l}\text { Potenti } \\
\text { al } \\
\text { Failure }\end{array}$ & $\begin{array}{c}\text { Potential } \\
\text { Effects of } \\
\text { Failure }\end{array}$ & $\begin{array}{c}\text { Severit } \\
\mathrm{y}\end{array}$ & $\begin{array}{l}\text { Inciden } \\
\text { ce rate }\end{array}$ & $\begin{array}{l}\text { Detecti } \\
\text { on }\end{array}$ & $\begin{array}{r}\mathrm{RP} \\
\mathrm{N}\end{array}$ & $\begin{array}{l}\text { Recomendat } \\
\text { ion }\end{array}$ & $\begin{array}{c}\text { Preventiv } \\
\text { e act }\end{array}$ & $\begin{array}{l}\text { Severi } \\
\text { ty }\end{array}$ & $\begin{array}{l}\text { Oc } \\
\text { c. }\end{array}$ & $\begin{array}{l}\text { Detek } \\
\mathrm{si}\end{array}$ & $\begin{array}{c}\mathrm{RP} \\
\mathrm{N}\end{array}$ \\
\hline 1 & 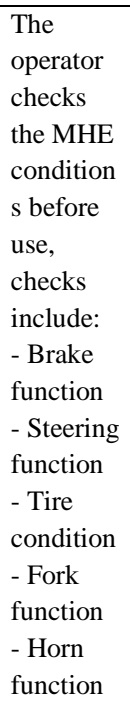 & $\begin{array}{l}\text { The } \\
\text { operato } \\
\mathrm{r} \text { raises } \\
\text { the } \\
\text { fork } \\
\text { while } \\
\text { turning } \\
\text { the } \\
\text { MHE } \\
\text { (blendi } \\
\text { ng } \\
\text { motion } \\
\text { ) }\end{array}$ & $\begin{array}{c}\text { MHE lost } \\
\text { bala } \\
\text { nce }\end{array}$ & 8 & 4 & 5 & $\begin{array}{c}16 \\
0\end{array}$ & $\begin{array}{l}\text { Conduct } \\
\text { pre-test and } \\
\text { post-training } \\
\text { tests }\end{array}$ & $\begin{array}{l}\text { Evaluatio } \\
\mathrm{n} \text { of } \\
\text { employee } \\
\mathrm{s} \text { with } \\
\text { low } \\
\text { scores }\end{array}$ & 8 & 3 & 4 & 96 \\
\hline 2 & $\begin{array}{l}\text { The } \\
\text { operator } \\
\text { honks the } \\
\text { horn } \\
\text { before } \\
\text { moving } \\
\text { the MHE }\end{array}$ & $\begin{array}{l}\text { The } \\
\text { operato } \\
\mathrm{r} \text { raises } \\
\text { the } \\
\text { fork } \\
\text { while } \\
\text { turning } \\
\text { the } \\
\text { MHE } \\
\text { (blendi } \\
\text { ng } \\
\text { motion } \\
\text { ) }\end{array}$ & $\begin{array}{l}\text { MHE fork } \\
\text { / body } \\
\text { nudges the } \\
\text { shelf } \\
\text { (Upright / } \\
\text { Beam) }\end{array}$ & 8 & 5 & 4 & $\begin{array}{c}16 \\
0\end{array}$ & $\begin{array}{l}\text { Employee } \\
\text { performance } \\
\text { appraisal } \\
\text { every month }\end{array}$ & $\begin{array}{l}\text { Providing } \\
\text { awards } \\
\text { for } \\
\text { employee } \\
\mathrm{s} \text { with the } \\
\text { highest } \\
\text { ratings }\end{array}$ & 8 & 4 & 3 & 96 \\
\hline 3 & $\begin{array}{l}\text { Advance } \\
\text { the MHE } \\
\text { to a } \\
\text { sufficient } \\
\text { distance } \\
\text { to retrieve } \\
\text { the pallet }\end{array}$ & $\begin{array}{l}\text { The } \\
\text { operato } \\
\text { r does } \\
\text { not } \\
\text { pull the } \\
\text { fork } \\
\text { slowly }\end{array}$ & $\begin{array}{l}\text { MHE } \\
\text { nudged } \\
\text { other MHE } \\
\text { who were } \\
\text { active }\end{array}$ & 9 & 4 & 4 & $\begin{array}{c}14 \\
4\end{array}$ & $\begin{array}{l}\text { Conducting } \\
\text { work area } \\
\text { observations }\end{array}$ & $\begin{array}{l}\text { Routine } \\
\text { occupatio } \\
\text { nal risk } \\
\text { assessme } \\
\text { nt }\end{array}$ & 9 & 3 & 3 & 81 \\
\hline
\end{tabular}


International Journal of Engineering Research and Advanced Technology, Vol. 7, No. 6, June -2021

\begin{tabular}{|c|c|c|c|c|c|c|c|c|c|c|c|c|c|}
\hline $\begin{array}{l}\mathrm{N} \\
\mathrm{O}\end{array}$ & Job desk & $\begin{array}{c}\text { Potenti } \\
\text { al } \\
\text { Failure }\end{array}$ & $\begin{array}{c}\text { Potential } \\
\text { Effects of } \\
\text { Failure }\end{array}$ & $\begin{array}{c}\text { Severit } \\
\mathrm{y}\end{array}$ & $\begin{array}{l}\text { Inciden } \\
\text { ce rate }\end{array}$ & $\begin{array}{l}\text { Detecti } \\
\text { on }\end{array}$ & $\begin{array}{l}\mathrm{RP} \\
\mathrm{N}\end{array}$ & $\begin{array}{c}\text { Recomendat } \\
\text { ion }\end{array}$ & $\begin{array}{c}\text { Preventiv } \\
\text { e act }\end{array}$ & $\begin{array}{l}\text { Severi } \\
\text { ty }\end{array}$ & $\begin{array}{l}\text { Oc } \\
\text { c. }\end{array}$ & $\begin{array}{l}\text { Detek } \\
\text { si }\end{array}$ & $\begin{array}{l}\mathrm{RP} \\
\mathrm{N}\end{array}$ \\
\hline 4 & $\begin{array}{l}\text { Operators } \\
\text { head to } \\
\text { the rack } \\
\text { area, and } \\
\text { honk their } \\
\text { horns as } \\
\text { they pass } \\
\text { through } \\
\text { intersecti } \\
\text { ons }\end{array}$ & $\begin{array}{l}\text { The } \\
\text { operato } \\
\mathrm{r} \text { does } \\
\text { not } \\
\text { raise } \\
\text { the } \\
\text { fork } \\
\text { end }\end{array}$ & $\begin{array}{l}\text { The } \\
\text { product } \\
\text { has fallen } \\
\text { off the fork } \\
\text { when } \\
\text { picked up }\end{array}$ & 9 & 4 & 4 & $\begin{array}{c}14 \\
4\end{array}$ & $\begin{array}{l}\text { Conduct } \\
\text { pre-test and } \\
\text { post-training } \\
\text { tests }\end{array}$ & $\begin{array}{l}\text { Evaluatio } \\
\mathrm{n} \text { of } \\
\text { employee } \\
\mathrm{s} \text { with } \\
\text { low } \\
\text { scores }\end{array}$ & 9 & 3 & 3 & 81 \\
\hline
\end{tabular}

In the RPN calculation above, it can be seen that the RPN value has decreased after taking corrective actions that focus on the work with the highest RPN value. The potential for the highest failure effect is that the forklift loses balance, has an RPN of 160, decreases to 96, then the fork or body of the forklift that hits the shelf has an RPN of 160 decreases to 96. Forklifts that bump other forklifts while operating have an RPN value of 144 and decrease to 81 . The potential for operator failure not lowering the fork has the RPN 144 value decreasing to 81 .

A decrease in the RPN value indicates that the improvements made affect reducing the level of danger and risk in the work area. One of the improvements made was to set the forklift lane in the rack area in one direction; this was done to prevent the meeting of two forklifts operating in the exact location and passing by on a narrow rack road. In addition, this change is also to reduce the movement of the forklift to turn, thereby reducing the risk of damage to the barrier due to scratches by pallets or forklift forks when turning.

\subsubsection{Future State Mapping}

Furthermore, a Future Stream Mapping is made, which is used to measure the time from receiving goods to sending goods. In the future state mapping, it appears that the processing time is longer due to changes in the path when storing and retrieving goods on the shelf. The following is a Future Value Stream Mapping from the results of the improvements made.

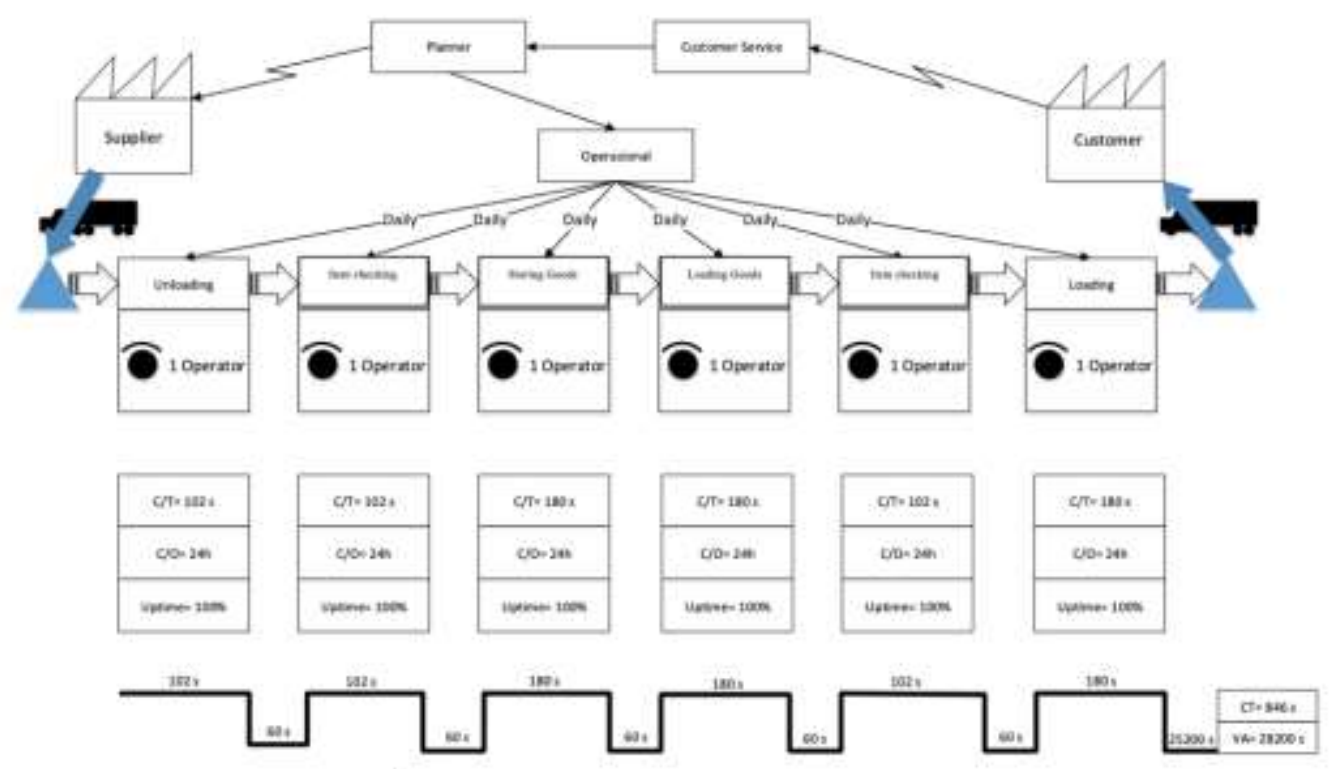

Figure 1 Future State Mapping of Goods Receiving and Shipping Process

From the future state mapping above, there is an increase in the time needed to carry out one work process; this change is because the forklift lane has been determined to be only one direction. The forklift is prohibited from turning or turning in the rack area. This results in a decrease in the value of the RPN and an increase in the quality of work safety in the rack area. 


\subsubsection{ProModel Simulation}

Improvements are then carried out with a ProModel simulation to determine the changes and their effects. The results of the ProModel simulation of the process of receiving and sending goods with an actual time of 21 hours and a processing time of 846 seconds in processing one pallet from entering the warehouse to the goods delivery process are run as follows:

1. Location

a. Total Entries

Total Entries is the number of entered and processed entities at the intended location; the resulting output is 396 pallets with a cycle time of 1146 seconds.

- Truck_incoming: 634

- Truck_Outgoing: 396

- Racking: 433

- Incoming_area: 534

- Outgoing_area: 389

b. Average Time per Entry (min)

At this stage, the average production time for each process is as follows:

- Truck_incoming: 171.07

- Truck_Outgoing: 0

- Racking: 97.22

- Incoming_area: 231.45

- Outgoing_area: 5,21

c. Maximum Content

The full content contained in this ProModel simulation is:

- Truck_incoming: 100

- Truck_Outgoing: 1

- Racking: 36

- Incoming_area: 100

- Outgoing_area: 2

d. Current Content

The current content describes the number of entries that were present when the simulation was stopped

- Truck_incoming: 100

- Truck_Outgoing: 0

- Racking: 35

- Incoming_area: 100

- Outgoing_area: 2

e. Utilization

The utilization or use capacity of each location in the simulation is as follows:

- Truck_incoming: $86.08 \%$

- Truck_Outgoing: 0\%

- Racking: $3.34 \%$

- Incoming_area: $98.09 \%$

- Outgoing_area: $1.64 \%$

f. Location State

- Location States (Multi-Cap) describes capacity usage from one another. The Location States (Multi-Cap) graph in the simulation of the actual time ProModel is as follows: 


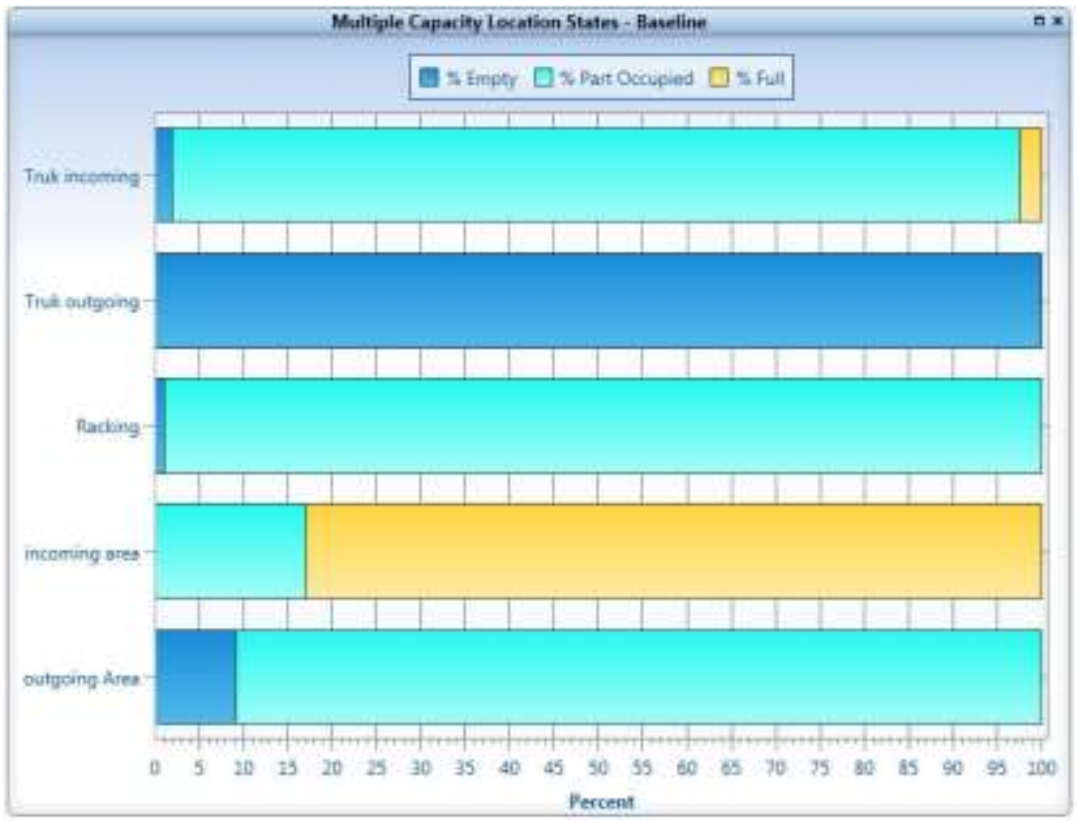

Figure 5.2 Location States (Multi-Cap) in ProModel Simulation Source: Data processed, 2020

In the Location States image above, locations that have multiple capacities are:

a. Truck_incoming

Percentage blank: $1.91 \%$

Percentage filled: $95.68 \%$

Complete percentage: $2.41 \%$

b. Truck_Outgoing: $0 \%$

Percentage blank: $100 \%$

Percentage filled: $0 \%$

Full percentage: $0 \%$

c. Racking: $0 \%$

Percentage blank: $1.08 \%$

Percentage filled: $98.92 \%$

Full percentage: 0\%

d. Incoming_area: $98.09 \%$

Percentage blank: 0\%

Percentage filled: $17.12 \%$

Full percentage: $82.87 \%$

e. Outgoing_area: $1.64 \%$

Percentage blank: $9.11 \%$

Percentage filled: $90.88 \%$

Full percentage: 0\%

\subsection{Discussion}

The use of Fishbone to analyze the causes of damage to facilities in the rack area is divided into four main factors.

a. The first factor is humans, operators who do not understand the risks of the work they are doing tend to be indifferent to the surrounding conditions because employees only pay attention to their main tasks without maintaining the supporting factors that support the work process, then do not operate forklifts or work equipment safely as expected - supposed to be done.

b. The second factor is related to a giant forklift, and in operation, it requires expertise and particular concentration, especially when carrying loads with a maximum load.

c. The third factor is the training system that was previously ineffective, as seen in the results of the pre-test assessment, where many operators did not meet the standard values, and the repair system for damaged facilities was not carried out regularly and on schedule.

d. The fourth factor relates to the rack environment, which is slightly wider than the forklift being used, making it difficult for the operator if two forklifts are working in the same rack ramp. 


\section{CONCLUSION}

\subsection{Conclusion}

The conclusions that can be drawn from this study are as follows:

1. Based on the description of the analysis in this study, it is concluded that reducing the work risk in the rack area with the DMAIC, VSM, and FMEA methods in logistics companies have generally been going well. This can be seen from the success in reducing work risk with the FMEA method, the calculation of RPN has a potential decrease from the highest failure effect, namely the forklift loses balance, has an RPN of 160, decreases to 96, then the fork or body of the forklift that hits the shelf, has an RPN. Amounting to 160 decreases to 96 . Forklifts that bump into other forklifts while operating have an RPN value of 144 and decrease to 81 . The potential for operator failure not lowering the fork has an RPN 144 value decreases to 81 . In making work safety improvements as a real action in To solve the problems faced by logistics companies, an evaluation was carried out by changing the forklift lane on the shelf into a one-way work process using VSM, through Future State Mapping, which is an application of the improvement results of Future Value Stream Mapping (FVSM) with FVSM cycle time of 846 seconds.

2. Simulations carried out using the ProModel application have been able to have an impact on reducing work risks. Simulations are carried out to adjust the forklifting path in the rack area; it appears that the forklift lane arrangement can reduce the risk of damage to the barrier in the rack junction area. The effect of this change causes the productivity that was previously more than the minimum productivity target, which is 23 pallets per hour, to decrease to the same as the productivity target, which is 20 pallets per hour, with an FVSM cycle time of 846 seconds and a run-time setting of 21 hours. The results of the total exits (goods that come out) amounted to 396.

\subsection{Suggestions}

Based on the research results, some suggestions as input for consideration are as follows:

1. The need for awareness of basic knowledge about work safety, process standards, and work risks because it has not been fully realized even though it has received training but only understands general terms.

2. In increasing concern for worker safety, support from top management is needed. The role of top management has two main aspects, namely providing leadership and providing the necessary resources.

3. Increase the quality of training materials and training mentors and conduct pre-test and post-test to determine the effectiveness of the training and the level of understanding of the training participants.

\section{ACKNOWLEDGMENT}

Universitas Mercu Buana Research Centre funded this research. We are grateful for all experts who are willing to be research partners, with no mention of the company name.

\section{REFERENCES}

[1] Evans.J.R and Lindsay.W.M. 2005. The Management and Control of Quality. Sixth Edition. Thompson, Singapore

[2] Haekal, J., Hanum, B., \& Adi Prasetio, D. E. 2020. Analysis of Operator Body Posture Packaging Using Rapid Entire Body Assessment (REBA) Method: A Case Study of Pharmaceutical Company in Bogor, Indonesia. International Journal of Engineering Research and Advanced Technology - IJERAT (ISSN: 2454-6135), 6(7), 27-36.

[3] Hanum, B., Haekal, J., \& Adi Prasetio, D. E. 2020. The Analysis of Implementation of Enterprise Resource Planning in the Warehouse Division of Trading and Service Companies, Indonesia. International Journal of Engineering Research and Advanced Technology - IJERAT (ISSN: 2454-6135), 6(7), 37-50.

[4] Kholil, M., Haekal, J., Eko Adi Prasetio, D. \& Sulaiman Hasan. 2020. The Lean Manufacturing Design For Improving Production Scheduling Using Product Wheel Method in Chemical Manufacturing Company, Indonesia. International Journal of Engineering Research and Advanced Technology - IJERAT (ISSN: 2454-6135), 6(8), 12-18.

[5] Haekal, J., \& Setio, H. 2017. Selection of Raw Material Suppliers Using Analytical Hierarchy Process in Food and Beverage Company, South Jakarta. ComTech: Computer, Mathematics and Engineering Applications, 8(2), 63-68.

[6] HAEKAL, J. (2018). Perancangan Dan Evaluasi Implementasi Sistem Manajemen Mutu Iso 9001: 2015 Melalui Kepuasan Pelanggan Di Universitas Islam As-Syafi'iyah (Doctoral dissertation, Universitas Mercu Buana Jakarta). 
International Journal of Engineering Research and Advanced Technology, Vol. 7, No. 6, June -2021

[7] Kholil, M., Haekal, J. H, Sulaiman. 2020. Lean Manufacturing Design to Reduce Waste in Gear Production Process Using VSM and Kaizen Method Approaches (Case Study: Gear Primary Driven K56 Product). Journal of Scientific and Engineering Research. 7(8), 1-9

[8] Haekal, J., \& Prasetio, D. E. A. Planning of Production Facilities Layouts In Home Industry With The Systematic Layout Planning Method.

[9] haekal, J., \& Setiawan, I. (2020). Comparative Analysis of Raw Materials Control Using JIT and EOQ method For Cost Efficiency of Raw Material Supply in Automotive Components Company Bekasi, Indonesia. International Journal of Engineering Research and Advanced Technology (IJERAT), 6(10), 76-82. https://doi.org/10.31695/IJERAT.2020.3661

[10] Haekal, J., Hanum, B., \& Adi Prasetio, D. E. 2020. Application of Quantitative Strategic Planning Matrix (QSPM) For Determination of Alternative Strategies in Food and Beverage SMES in Bogor Indonesia. Journal of Scientific and Engineering Research. 7(7), 137-145

[11] Hanum, B., Haekal, J., \& Adi Prasetio, D. E. . 2020. SPHC Material Inventory Control Analysis in Project VL01 Centralized by the EOQ Method in Automotive Company Indonesia. Journal of Scientific and Engineering Research. $7(7), 130-136$

[12] Ikatrinasari, Z. F., Hasibuan, S., \& Kosasih, K. (2018, November). The implementation lean and green manufacturing through sustainable value stream mapping. In IOP Conference series: materials science and engineering (Vol. 453, No. 1, p. 012004). IOP Publishing.

[13]Evans.J.R and Lindsay.W.M. 2007. An Introduction to Six Sigma \& Process Improvement. Salemba Empat, Jakarta [14]Vincent Gaspersz. 2011. Lean Six Sigma For Manufacturing and Service Industries. Vinchristo Publication, Bogor. [15] Hasan, M Iqbal. 2002. Main Contents of Statistics 1 (Descriptive Statistics). Second Edition. PT. Earth Literacy, Jakarta. [16]Arikunto, Suharsimi. 2002. Research Procedure A Practical Approach. Revised Edition IV. Rineka Cipta, Jakarta. [17] Gaspersz, Vincent, 2012, All In One: Production and Inventori Management, Edisi 8, Vinchristo Publication, Bogor.

[18] Nazir, M. 1988. Research Methods, Ghalia Indonesia, Jakarta

[19] Sutopo. 2006. Metodologi Penelitian Kualitatif. UNS, Surakarta.

[20] Kholil, Muhammad, Jakfat H., \& Sulaiman H. 2020. Lean Manufacturing Design to Reduce Waste in Gear Production Process Using VSM and Kaizen Method Approaches (Case Study: Gear Primary Driven K56 Product). Journal of Scientific and Engineering Research

[21] Kholil, Muhammad, Jakfat H., Dian E.A., \& Sulaiman H. 2020. The Lean Manufacturing Design for Improving Production Scheduling Using Product WheelMethod in Chemical Manufacturing Company. International Journal of Engineering Research and Advanced Technology

[22] Soehatman, Ramli. 2010. Practical Guidelines for Fire Management (Fire Management). Dian Rakyat, Jakarta

[23] Soehatman, Ramli. 2010. Pedoman Praktis Manajemen Risiko dalam Perspektif K3 OHS Risk Management. Dian Rakyat, Jakarta

[24] Arikunto, S. (2010). Research Procedure A Practical Approach. Jakarta: Rineka Cipta

[25] OHSAS:18001. 2007. Occupation Health and Safety Management System.

EMAIL: Jakfat.haekal@mercubuana.ac.id 